\title{
Mathematics or Physics-Majored Students on the Biomedical Fields, Insiders or Outsiders?
}

\section{Lu DY' ${ }^{*}$ and Lu TR}

${ }^{1}$ School of Life Sciences, Shanghai University, Shanghai200444, PR China

${ }^{2}$ College of Science, Shanghai University, Shanghai200444, PR China

\section{Abstract}

Mathematics- or physics-majored students are disciplinary, sensitive to numbers and mathematical imagination. They play unique roles in biomedical science now. This editorial offers new insights in this matter and possible future perspectives.

Keywords: Mathematics; Physics; Systems biology; Human genome; Biology; Medicine

\section{Introduction}

\section{Background}

It is well-known that mathematics- or physics-majored students are different from biological or medical majored students. The former types of students are disciplinary, sensitive to numbers and mathematical imaginations. Biological- or medical students are, however, advantageous at experimenting and operations. These two types of students were previously trained for various purposes and utilities. Yet, mathematics- or physics-majored students are versatile now. Formerly, long-term trained medical courses can be quickly understood by mathematics- or physics-majored students from modern educational systems, such as web- or TV educational channels. Similarly, biomedical-majored students are required to handle a great numbers of mathematic data owing to growing numbers of biomedical information in every parameter of pathogenesis pathways and therapeutic efficacy or toxicities quantifications.

\section{New insights}

Facing this situation, mathematics- or physics-majored students may be more suitable than biomedical-majored students in large-sized genetic or bioinformatics analysis and pinpointing. Currently, we may no longer call mathematics- or physics-majored student "layman" in biomedical studies. Previously, we speculated that mathematics- or physics-majored students can be the major-forces in genomic studies in both DNA drafting and post-genome analysis [1,2]. Similarly, in systems biology studies, theoretic physic-majored students or scholars are proposed to be one of the commonest participants in scientific investigations of modern biology [3].
Recently, a lot of mathematicians are seeking opportunity in industrial, especially in Pacific areas [4]. Whether positive or negative, this type of activities is an inevitable pathway and fate for mathematical or theoretical physics-majored students. Their capabilities are admirable. If growing quality of cooperation between mathematical/ physical scholars and biomedical scholars is realized, dramatic changes in life science are foreseeable.

The authors of this editorial are one of biomedical-major and one of theoretic physics major. With the time goes by, we are more satisfactory with our cooperation. We have published more coauthored articles than separated articles.

\section{Conclusion}

It is a good sign that a lot of researchers with mathematics- or physics- backgrounds are coming onto biomedical fields. Hopefully, increasing milestone work can be expected, such as the wonderful cooperation between Watson and Crick (a biologist and a physicist).

\section{References}

1. Lu DY, Lu TR, Che JY, Wu HY, Xu B (2014) New perspectives of HIV/AIDS therapy study. Recent Pat Antiinfect Drug Discov 9: 112-120.

2. Lu DY, Lu TR, Che JY, Zhu PP (2014) Genetics and bioinformatics studies of antidepressant drug therapeutic efficacies and toxicities, a current overview. Recent Pat CNS Drug Discov 9:193-199.

3. Pennisi E (2003) Tracing life's circuitry. Science 302: 1646-1649.

4. Normile $D$ (2015) Pacific rim mathematicians coaxed from their ivory towers. Science 350: 616

*Corresponding author: Lu DY, School of Life Sciences, Shanghai University Shanghai200444, PR China, Tel: +862166163545; Fax: +862166132177; E-mail: ludayong@shu.edu.cn

Received November 27, 2015; Accepted December 02, 2015; Published December 04, 2015

Citation: Lu DY, Lu TR (2015) Mathematics or Physics-Majored Students on the Biomedical Fields, Insiders or Outsiders? Metabolomics 6: e142. doi:10.4172/2153 $0769.1000 \mathrm{e} 142$

Copyright: (C) 2015 Lu DY, et al. This is an open-access article distributed unde the terms of the Creative Commons Attribution License, which permits unrestricted use, distribution, and reproduction in any medium, provided the original author and source are credited. 